\title{
ESSENCE AND EXISTENCE IN AVICENNA AND AVERROES ${ }^{1}$
}

\section{ESENCIA Y EXISTENCIA EN AVICENA Y AVERROES}

\author{
CATARINA Belo \\ The American University in Cairo
}

This article explores the views on existence of medieval Muslim philosophers Avicenna (d. 1037) and Averroes (d. 1198), whose works followed closely the philosophy of Aristotle. In addition to the Aristotelian influence, which permeated all medieval Islamic philosophy, Avicenna and Averroes were also inspired by Islamic theology, known in Arabic as kaläm. The distinction between essence and existence is one of the most central and controversial aspects of Avicenna's philosophy, together with his claim that existence is an accident. Averroes in turn has a radically different conception of existence, identifying it with existing beings rather than considering it as something in itself. With the Latin translation of Avicenna's metaphysical works in the $12^{\text {th }}$ century, the Avicennian distinction went on to shape much of the debate on existence in medieval Scholastic philosophy and beyond. This article assesses the meaning of the distinction in Avicenna as well as Averroes' criticism. In explicating their radically different views on existence, it also touches on later discussions concerning existence, for example the issue whether existence is a predicate, in the Modern Age.

Key words: Avicenna; Averroes; Essence; Existence; Predicate; Kalām.
El presente artículo explora las percepciones sobre la existencia de los filósofos medievales musulmanes Avicena (m. 1037) y Averroes (m. 1198), cuyas obras se encuentran muy próximas a la filosofía de Aristóteles. Además de la influencia aristotélica, que caló en toda la filosofía islámica medieval, Avicena y Averroes estuvieron inspirados por la teología islámica, conocida en árabe como Kalām. La distinción entre esencia y existencia es uno de los más fundamentales y controvertidos aspectos de la filosofía de Avicena junto a su aseveración de que la existencia es un accidente. Averroes, en cambio, concibe de forma radicalmente diferente la existencia, identificándola con los seres existentes más que considerarla como algo en sí misma. Con la traducción al latín de los trabajos de metafísica de Avicena en el siglo XII, su distinción prosiguió modelando el debate sobre la existencia en la filosofía escolástica medieval y más allá. Este artículo evalúa el significado de la distinción en la crítica tanto de Avicena como de Averroes. Al explicar sus concepciones, radicalmente distintas, de la existencia se establece un contacto con posteriores discusiones concernientes a la misma, como, por ejemplo, la cuestión de si la existencia es un predicado, en la edad moderna.

Palabras clave: Avicena; Averroes; esencia; existencia; predicado; kalām.

1 I am grateful to Professor Puig Montada and the anonymous reviewers for their comments and suggestions on this article. 
The distinction between essence and existence is one of the most central and controversial aspects of Avicenna's (Arabic Ibn Sīnā, d. 1037) philosophy. Like other theories propounded by Avicenna it came under the criticism of Averroes (Arabic Ibn Rushd, d. 1198), the highest exponent of the philosophical tradition in medieval Islamic Spain. Averroes held a radically different view on the relationship between essence and existence and more generally on ontology. Nevertheless the debate was not confined to Arabic philosophy. Through Latin translations of Avicenna's and Averroes' works the debate influenced medieval Christian philosophy. Firmly rooted in Aristotelian ontology, the controversy remains relevant in contemporary philosophy because it prefigures modern discussions on existence, more specifically whether existence is a predicate, such as those of Kant and more recently B. Russell and G.E. Moore.

Recent scholarship on Avicenna focuses on the meaning of his distinction between essence and existence. Opinions vary on whether he truly distinguishes essence from existence in concrete beings and considers existence an accident. The most complete study to date is A.M. Goichon's authoritative work entitled La Distinction de l'essence et de l'existence d'après Ibn Siña (Avicenne), an in-depth analysis of Avicenna's philosophy and metaphysics. Goichon takes the distinction to be real in the sense that essence is privileged over existence and the latter is considered an accident of the substance in relation to its essence. ${ }^{2}$ Her interpretation has been challenged by the likes of P. Morewedge, who considers that Avicenna does not make a real distinction between essence and existence. ${ }^{3}$ More recently S. Pessin too holds that "Avicenna does not literally treat existence as an accident". ${ }^{4}$ Some scholars who claim that the distinction is not real point to the absurdity of treating existence as an accident in rela-

${ }^{2}$ Goichon, A.M., La distinction de l'essence et de l'existence d'après Ibn Siñā (Avicenne), Paris, 1937, 136-139.

3 This view is shared by Cunningham, F., "Averroes vs. Avicenna on Being", New Scholasticism, 48 (1974), 185-218, 201.

${ }^{4}$ Pessin, S., "Proclean 'Remaining' and Avicenna on Existence as Accident. Neoplatonic Methodology and a Defense of Pre-Existing Essences", in J. Inglis (ed.), Medieval Philosophy and the Classical Tradition, in Islam, Judaism and Christianity, London, 2002,151 . Wisnovsky's analysis focuses on the difference between thing and existent, rather than essence and existence, but, without taking sides, cites passages in which Avicenna distinguishes essence and existence, Wisnovsky, R., Avicenna's Metaphysics in Context, London, 2003, 155. 
tion to the essence, which would play the role of substance. Since a substance has to actually exist in order to receive accidents, what would this "pre-existence" of the essence mean? 5

More often than not Avicenna's approach has been studied without taking into account Averroes, one of his staunchest opponents on this and other philosophical problems. An exception to an exclusive sole focus on Avicenna is García Marqués' thorough and insightful analysis in an article entitled "La polémica sobre el ser en el Avicena y Averroes Latinos" ("The controversy over being in the Latin Avicenna and Averroes"). ${ }^{6}$

The origin of the differentiation between essence and existence is debated in contemporary scholarship. While some argue that it was seminally present in Plato and fairly explicit in Aristotle, more recently scholars have stated that rather than drawing solely on Aristotle Avicenna was in fact primarily influenced by kalām, Islamic speculative theology. ${ }^{7}$ More specifically, some Muslim theologians,

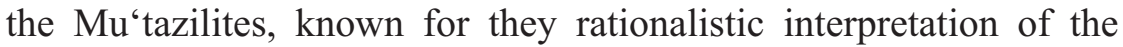
Qur'ān, advocated that essence precedes existence. ${ }^{8}$ Islamic theol-

5 Pessin, "Proclean 'Remaining"”, 153.

6 García Marqués, A., "La polémica sobre el ser en el Avicena y Averroes Latinos", Anuario Filosófico, Universidad de Navarra, XX, 1 (1987), 73-104. Cunningham, in his "Averroes vs. Avicenna on Being", harmonises the views of the two philosophers. He claims that neither Averroes nor Avicenna held a strict differentiation between essence and existence, while both defended the theory of a conceptual separation, see 195-6 and 201

7 Goichon, in La distinction de l'essence, 132, ascribes the distinction to Aristotle in his Posterior Analytics. Anal. Post., II, 7, 92b 10-11, where Aristotle states "what man is, and (there) being a man is different". Wisnovsky supports the view, already put forth by Jean Jolivet, that the distinction is in fact based on kaläm debates on the relationship between "thing" (shay') and existent (mawjüd), see Wisnovsky, R., "Notes on Avicenna's Concept of Thingness (shay'iyya)", Arabic Sciences and Philosophy, 10, 2 (2000), 181-221, in particular 181-200. In expounding Avicenna's position, Wisnovsky also distinguishes between "specific existence", in effect essence, and "affirmative existence", existence proper. "To predicate affirmative existence of an entity is to assert that the entity is, not what the entity is", 193.

8 '... selon eux [les mu'tazilites], l'acte divin créateur est à concevoir strictement comme le fait de conférer l'existence à des essences déjà constituées", Gimaret, D., $L a$ doctrine d'al-Ash 'arī, Paris, 1990, 369. Jolivet expands on the issue: "Fakhr al-dinn al-Rāzī, dans son Muhașșal, où il traite notamment de ce problème classique de l'inexistant, nomme Ibn Sīnā en présentant 'la thèse des philosophes et des Mu'tazilites sur les choses inexistantes'; il cite d'abord plusieurs Mu 'tazilites, notamment al-Šaḥhām, les deux Ğubbā' '̄, et 'Abd al- Ğabbār, pour qui les inexistants possibles sont des essences (dhawāt, a yān, haq '̄a'iq) avant d'entrer dans l'existence: l'Agent n'en fait pas des essences, mais les fait exister; ces essences sont personnellement distinctes, et on peut leur

Al-Qanțara (AQ) XXX 2, julio-diciembre 2009, pp. 403-426 ISSN 0211-3589 
ogy, known as kalām (meaning "debate" or "dispute" in Arabic) differs markedly from Christian theology insofar as it does not consist in an established body of doctrine; rather the designation describes the medieval debate(s) over religious matters pertaining to Islam. Those discussions originated in and were based on the exegesis of the Qur'ān. Typical issues included God's attributes and their relation to the Godhead, and the divine nature more generally. The $\mathrm{Mu}$ 'tazilites were considered to be rationalists because they were inclined to reject anthropomorphic attributes of God featuring in the Qur'ān. ${ }^{9}$ For this reason they also advocated a metaphorical interpretation of the Qur'ān, especially in the case of ambiguous or seemingly contradictory passages. They were known as the champions of (God's) justice and unity (ahl al-'adl wa-l-tawhìd). Their focus on God's oneness

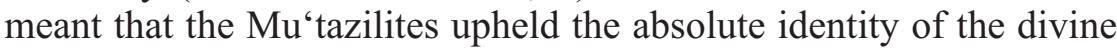
attributes with God - in short, they were not to be considered separate entities in their own right, which would compromise God's oneness. Ironically, the founder of the kalam school that would become the most famous opponent of the Mu'tazilites, al-Ash'arī, was himself a Mu'tazilite until the age of forty. Intent on a more literal reading of the Qur'ān the Ash'arites claimed that the attributes were real entities, distinct from God's essence.

The Muslim philosophers in the Greek, more specifically Aristotelian, tradition, were conversant with the preceding debates, and although not avowedly identifying with either of these schools tended to be closer to the Mu'tazilites. They preferred, for instance, their views on a metaphorical reading of the Qur'ān, and tended to side with their interpretations of the Qur'ān. For the Mu'tazilites, the debate over God's nature and attributes revolved around Qur'ānic passages to the effect that "God is powerful over all things" (2:20). In addition, certain passages seem to suggest there God is unlike anything else: "nothing is like him" (42:11). ${ }^{10}$ On the other hand, other passages seem to imply that God is in some way a thing, such as verse

attribuer une infinité de caractères. Pour les philosophes, poursuit-il, la quiddité des possibles est distincte de leur existence et on peut les mettre à part de l'existence extérieure", Jolivet, J., “Aux origines de l'ontologie d'Ibn Sīnā”, in Études sur Avicenne, dirigées par J. Jolivet et R. Rashed, Paris, 1984, 18.

9 Their contention that the Qur'ān was created (as opposed to being the eternal word of God) was in line with their view that only God is eternal.

10 All translations are mine unless otherwise stated.

Al-Qanțara (AQ) XXX 2, julio-diciembre 2009, pp. 403-426 ISSN 0211-3589 
6:19, "Say, which thing is greatest (as) witness, say God is witness between you and me". ${ }^{11}$ Avicenna appears to have been influenced by their discussion of what constituted a thing, although, as Jolivet points out, he translates the discussion over the relationship between thing and existence, and whether something that does not exist is a thing, as treated by the Muslim theologians, into a philosophical theory of the relation between essence and existence. ${ }^{12}$

As noted above, the distinction has come under scrutiny since the Middle Ages because it goes hand in hand with an essentialist view of entities and a study of essence in isolation from existence. From this it is only a short step to admitting that existence is a predicate or worse, something in is own right. Does this contradict the non-essentialist views of Aristotle who asserts that being is said in many different ways? Avicenna's and Averroes' views on existence open the field to modern debates and what it means to say that something exists. The Avicennian distinction between essence and existence went on to become extremely influential, playing for instance a central role in Descartes's ontological argument for God's existence in the Fifth of his Meditations on First Philosophy.

Although much has been written about the distinction in Avicenna and Averroes, the topic is far for being exhausted. In what follows I shall take into account some of the major texts by Avicenna and Averroes, including some that to my knowledge have hitherto been overlooked, such as for instance Avicenna's "Discussions" (al-Mubāhathāt in the original Arabic). The comparison between the two philosophers is in my view important not only to put into focus such diametrically opposed theories on existence as were those of Avicenna and Averroes but also in illustrating the polemic which ensued in the wake of Avicenna's formulation. Moreover, although the debate revolves primarily around ontology and the issue of existence,

11 Wisnovsky, Avicenna's Metaphysics, 146-147.

12 “.... notre étude a montré que l'ontologie d’Ibn Sīnā est héritière de ces controverses. Certes elle en transpose le contenu dans le registre particulier à la philosophie, elle l'associe à la pensée d'Aristote, et même réduite à ses thèses principales elle ne recouvre exactement aucune des doctrines qu'on a vues; mais elle en est tributaire jusque dans le détail du vocabulaire, de la problématique, et des analyses... Il reste vrai, bien entendu, qu'il doit beaucoup par ailleurs à Aristote et au néoplatonisme; mais c'est dans le kalām que s'est préparée sa doctrine de l'essence, qui est sans doute l'élément principal de son ontologie", Jolivet, "Aux origines", 24. 
it prompts further discussion on metaphysical questions such as modalities and causality. In addition to explaining the reasons for Averroes' criticism of Avicenna's formulation of existence as accident I shall seek to explain the sense in which existence is an accident for Avicenna and the sense in which it is not. I shall also endeavour to show that Avicenna's position and Averroes' criticism are grounded on the radically different philosophical positions about the generation of ephemeral beings, existence, and causal relations obtaining in the world.

\section{Avicenna's distinction between essence and existence}

In what does Avicenna's distinction between essence and existence consist? Does it mean that essence is to be found independently of actual realisation, and does this entail a contradiction? Is there an ambiguity in Avicenna's exposition? Opinions are divided mainly because on the one hand Avicenna states that existence is a primary intelligible which is not reducible to, or explicable through, other concepts. On the other hand he states in no uncertain terms that existence is an accident ( ' $\mathrm{arad}$ ). If existence is an accident it can only be understood through the essence of a primary substance, since accidents only exist by inhering in a substance, and hence they exist and are conceived only as part of that complex.

In what context does Avicenna make these statements?

Regarding the primacy of the concept of existence, Avicenna states, in the Book of Knowledge (Persian Dānishnäma):

The intellect knows being (hasti) without [recourse to a] definition and without description, because being has no definition; since it has no genus or difference (fasl), nothing is more common than it; and it does not have a description, and nothing is better known than it. Indeed one may know its name in one language without knowing it in another language. Then one proceeds to explaining with a particular term what it means. For example if one says it in Arabic, one explains it or points out in Persian that it is that under which all things come. Thus in first instance being (hast $\vec{l}$ ) is said in two ways, as substance and as accident. ${ }^{13}$

Understood in its most general sense, existence or being (hasti in Persian or wujüd in Arabic) is a primary intelligible, indeed the most

13 Avicenna, Dānishnāma, Ilāhiyyāt, E. Mu'in (ed.), Tehran, 1952, 8-9.

Al-Qanțara (AQ) XXX 2, julio-diciembre 2009, pp. 403-426 ISSN 0211-3589 
general, all-encompassing concept. It cannot be reduced to any other concept or divided into components, such as genus and difference, and is as such indefinable. As an immediate given to the intellect, it applies to all beings. It is also worth nothing that for Avicenna existence includes also mental concepts. Everything one might conceive exists in a certain way, be it mental or real. ${ }^{14}$ It is on the basis of this passage of the Book of Knowledge, his philosophical encyclopaedia in Persian, that Morewedge bases his critique of those, like Goichon, who see in Avicenna a separation between existence and essence. Morewedge criticizes medieval philosophers like Averroes and Aquinas for misconstruing this distinction in Avicenna but he extends his criticism to modern scholarship on the grounds of their ignoring Avicenna's Dānishnāma (The Book of Knowledge) and relying primarily on Avicenna's Arabic philosophical encyclopaedia, al-Shifä (The Healing). In particular Morewedge states that the Persian term hasti is broader than the Arabic term wujūd, in the sense that wujūd would have a stronger existential sense, whereas hastī should more aptly be translated as "being". ${ }^{15}$ However in the above passage, Avicenna appears to consider the Persian and Arabic terms as equivalent. In addition the equivalence between the Persian and the Arabic terms is reinforced in al-Shifä' where Avicenna offers a similar explanation of existence:

"Existent" (al-mawjūd), and "thing", and "necessary" are concepts (ma'nā) which are inscribed in the soul in a primary way... without [having recourse to] things better known than these... the things worthier of being imagined by themselves are the things common to all, as for example "being", "thing", "one". ${ }^{16}$

In these passages being is a primary concept and hence the conclusion, drawn by Morewedge and Cunningham, that Avicenna did not really think of existence as accident. Together with "existent", Avicenna considers "thing", "one" and "necessary" as primary con-

14 "Avicenna will grant the same extension to both shay' [thing] and mawjüd [existent] and will give the status of true 'being' to anything conceived in the mind since for him mental existence is a type of true existence", Druart, T.A., "Shay' or Res as Concomitant of 'Being' in Avicenna", Documenti e Studi sulla tradizione filosofica medievale, XII (2001), 125-142, 130.

${ }_{15}$ Morewedge, P., "Philosophical Analysis and Ibn Sīnā's 'Essence-Existence Distinction"”, JAOS, 92 (1972), 425-435, 429, n. 26.

16 Avicenna, al-Shifä', al-Ilāhiyyāt, G. Anawati (ed.), Cairo, 1960, 29.

Al-Qanțara (AQ) XXX 2, julio-diciembre 2009, pp. 403-426 ISSN 0211-3589 
cepts. The interdependence between "existent" and "necessary" is buttressed at another passage:

The necessary ( $a l$-wäjib) indicates certainty $\left(t a^{\prime} a k k u d\right)$ of existence and existence is better known than non-existence, because existence is known by itself and non-existence is known, in a certain way, through existence. ${ }^{17}$

In highlighting the parallelism between necessity and existence, Avicenna again stresses the primacy of the concept of existence, holding that both are absolutely self-evident concepts. Indeed existence is such an evident concept that non-existence is understood through it, as its negation. Other comments on existence stress existence as a primary concept, in contrast to accident which can only be understood through a substance in which it inheres. ${ }^{18}$ After stating that such notions as "existent", "thing" and "necessary" are inscribed in the mind in a primary way, in a suggestion that they are primary concepts, ${ }^{19}$ he goes on to add that in a thing one ought to distinguish its particular reality (haqiqa khāṣa) and affirmed existence. ${ }^{20}$ Existent means for Avicenna affirmed and realised existence, as opposed to the essence of a thing, which is associated with reality, and quiddity (mähiyya). As Jolivet puts it, "thing" is not understood as affirmative existence. But Avicenna also remarks that these terms are co-implied. ${ }^{21}$ Nevertheless the passage bears primarily on the terms in the mind, and naturally Avicenna does not want to deny that certain representations in the mind have no correspondence outside it. Hence his distinction between the essence of something, such as a triangle, whose essential, defining characteristics are in the mind, and the existence of an actual triangle outside the mind. They are naturally, undisputedly, two different things. To sum up, one can distinguish between thing and existent, and further one can distinguish in a "thing" between essence and existence, as Avicenna explicitly states.

17 Ibidem, 36.

18 Avicenna, al-Shifä', al-Maqūlāt, I. Madkūr (ed.), Cairo, 1959, 28 and 32 for Avicenna's views on the relationship between substance and accident. According to him, following the standard Aristotelian line, the accident only subsists when inhering in a substance, whereas the substance does not require the accident in order to subsist.

19 Avicenna, al-Shifä', al-Ilāhiyyāt, 29.

20 Ibidem, 31.

21 Jolivet, "Aux origines", 12, and Wisnovsky, Avicenna's Metaphysics, 152, for a discussion of this passage.

Al-Qanțara (AQ) XXX 2, julio-diciembre 2009, pp. 403-426 ISSN 0211-3589 
In a subchapter of the Metaphysics of the Book of Knowledge Avicenna addresses the relationship between being and the ten Aristotelian categories, comprising substance and the nine accidents. He states that existence is neither a genus over and above the ten categories nor said univocally of the ten categories, which means that it is not any one entity (i.e., substance) or to be understood univocally. Neither is it one of the remaining nine categories, the accidents of substance. ${ }^{22}$ In this sense existence is not a universal over and above the ten categories. Avicenna goes on to say that existence is predicated equivocally (mushakkak) of the ten categories, first of the substance and subsequently of the remaining nine accidents. It is in this sense that existence is also predicated (in the Book of Knowledge) according to priority and posteriority. Existence is said primarily of substance and as such it is then said of the accidents which inhere in a primary substance. Predication according to priority and posteriority means that it is said of the nine accidents through the intermediary of substance, and of some accidents through the intermediary of others. It is also said according to more or less (kamābish $\vec{\imath}$. Does this point to a gradation of being, or is it merely a repetition of what went before, namely the priority of substance in the predication of existence? Does it entail a contradiction? For on the one hand existence is a general concept over and above the ten categories, while it is not a genus, a universal. It transcends the categories and the five Porphyrian predicables, genus, species, differentia, accident, property. Existence is a general concept primarily apprehended by the mind. In the medieval Latin tradition, being or "ens" went on to become one of the transcendentals, together with unum (one), bonum (good), and verum (true) because these terms are more general and as such are above the ten Aristotelian categories. ${ }^{23}$ But Avicenna also says that existence is

22 Avicenna, Dānishnāma, Ilāhiyyāt, 36-37.

23 Janssens holds that the medieval Christian doctrine of the transcendentals is grounded on Avicenna's metaphysics, "according to Avicenna, at least the Avicenna Latinus, the notions ens, unum, res, and necesse are imprinted originally in the soul. This affirmation certainly lies behind the Latin medieval theory of the transcendentals, even if the latter, as exemplified e.g., in Thomas Aquinas, implies several modifications, the most important seeming to be the replacement of the primacy of 'thing' (res) by that of 'being", Janssens, J., "Elements of Avicennian Metaphysics in the Summa", in G. Guldentops and C. Steel (eds), Henry of Ghent and the Transformation of Scholastic Thought, Leuven, 2003, 41-59, 52. Janssens contends that in addition to ens and unum, necesse was possibly converted into bonum, and res into verum, ibidem, 53-56.

Al-Qanțara (AQ) XXX 2, julio-diciembre 2009, pp. 403-426 ISSN 0211-3589 
said according to quantity, more or less, which might be construed as a reification of existence, as if existence could be quantified. Avicenna also speaks of a universal sense of existence while stating that the existence of each substance is particular to it (khasss). ${ }^{24}$ These seem to be contradictory views on existence. In short, on the one hand existence is a general concept which goes hand in hand with substance, on the other certain aspects of his theory involve a reification of existence. Avicenna goes on to declare in the same passage what seems to be at odds with the opening lines of the chapter on the relationship between existence and the ten categories. While existence is said of substance and, through substance, of the remaining categories, there is a sense in which the link between existence and the categories is tenuous. Avicenna states that the concept of existence, in relation to the ten categories, is not essential (dhäti $)$. Here Avicenna reverts to the distinction between essence/substance and existence. This difference is based on causality. The example adduced by Avicenna is that something cannot be made to be a substance, at the logical level. But something can be made to exist. One may say that something was made to exist, but not that something was made a substance. The notion of substance and other accidents in abstract do not imply causality, but existence does. I would propose that one could discern here a distinction between a logical and a metaphysical understanding of substance and existence.

In abstract terms, then, existence is not an accident but a general concept. Once the notion of causality is introduced existence becomes an accident. In fact Avicenna rounds off this passage by hinting that existence is an accident. Like the accident "one", he argues, existence is not essential or a genus although it is predicated of all things. ${ }^{25}$

An apparent contradiction remains, for the theory of existence as an accident is incompatible with the first claim that existence is a primary concept. On the one hand existence is more general than the ten categories. On the other existence is an accident of substance or essence, hence is only understood in relation to, and as subordinated to, substance, and is not an essential or primary concept. In effect

${ }^{24}$ Avicenna, Dānishnāma, Ilāhiyyāt, 37.

25 Avicenna, Dānishnāma, Ilāhiyyāt, 39. The understanding of this passage is further complicated by the use of anniyya, a term apparently used to denote existence as opposed to quiddity (mähiyya), although in other contexts anniyya means essence.

Al-Qanțara (AQ) XXX 2, julio-diciembre 2009, pp. 403-426 ISSN 0211-3589 
Avicenna seems, unlike Aristotle, to understand the primacy of substance as a primacy of essence, rather than of existence in relation to existing primary substances.

However Avicenna defends the primacy of the concept of existence. In al-Shif $\bar{a}$ ' he distinguishes the essence of a thing from its existence. He does state equally that existence is an accident. The accidental quality of existence is supported by his well-known distinction between existence and essence, stated in the same work as his view on the primacy of the concept of existence. How to explain this seeming contradiction? It is not the case that Avicenna held a particular view on existence or the relationship between essence and existence to reject it later. The two views are put forth concurrently only lines away in the same works. In what consists the difference between essence and existence? Avicenna was considered to conceive of essence as independent of, and prior to existence. As we have seen, the essence is uncaused whilst existence is caused, in what appears to echo $\mathrm{Mu}$ 'tazilite views on the relation between thing and existent. Thus in an abstract way one may conceive an essence without conceiving its existence, and could thus think of a chronological precedence of essence over existence. García Marqués associates in Avicenna essence considered as possibility with existence as necessity. ${ }^{26}$ Many scholars have held that there is a contradiction between these two theories of existence and tried to exonerate Avicenna by stating that he held one or the other view. In my opinion these views are held concurrently by Avicenna and it is possible to explain away the apparent contradiction between the two.

Clearly, it is with the introduction of the concept of causality, at a metaphysical level, that existence comes to be seen as an accident, in a metaphysical rather than logical sense as something that befalls the essence or thing. As noted by several scholars the issue of existence as accident originates in Avicenna's metaphysical system. There are thus two senses of existence, as a primary concept and as an accident. In general terms, existence is irreducible to any other concept. When one thinks of the metaphysical and causal structure of the universe, though, existence becomes an accident in existing substances, with the exception of God. A passage in al-Mubāhathāt (The Discussions) sums up Avicenna's narrower understanding of existence:

26 García Marqués, "La polémica sobre el ser”, 80-81.

Al-Qanțara (AQ) XXX 2, julio-diciembre 2009, pp. 403-426 ISSN 0211-3589 
It was asked: existence is an accident ('arad); since it was shown that the necessary existent is neither an accident nor a substance, what is the difference between the two existences?

$\mathrm{R}$ (eply). Existence is an accident in the things which have quiddities that come before their existence. As for that which exists by its essence, it does not exist through an existence that comes after its quiddity, as a foreign thing, not included in the definition ( $h a d d$ ). There is no existence through which it exists - let alone that existence should be an accident of it - rather it exists by its essence. ${ }^{27}$

In actually existing beings whose essence does not automatically entail existence, existence becomes an accident. That is to say, existence is an accident in all beings other than God.

In speaking of existence in general Avicenna asserts its primacy, in his metaphysical system he states that existence is granted by God.

The necessarily existent has no quiddity (mähiyya) except that it is necessarily existent, and this is the fact that it exists (anniyya)... Everything whose quiddity differs from its existence (anniya) is caused $(m a l \bar{u} l)$... Its existence comes from a cause. Everything that has a quiddity is caused, and the remaining things other than the Necessarily existent have quiddities, and those quiddities are by themselves possibly existent; existence only befalls them from outside. ${ }^{28}$

However, Avicenna himself explicitly rejects the absurd contention that "the quiddity would exist in itself before existing". ${ }^{29}$ Hence the separation is primarily conceptual, and there is an absolute consistency in Avicenna's views for he famously held that the possible is by definition the non-existent. In his modal metaphysics everything that exists is made necessary by its cause, and the possible does not exist, and ceases to be possible once it begins to exist.

Thus when speaking of actually existing beings, only in God is essence and existence identical. In other beings existence is added as an accident. This position serves to preserve divine omnipotence and uniqueness. It is only through God that beings come to exist. It also highlights the complete dependence of other beings on God for their existence. All existence according to this view is bestowed by God. This does not mean to say that essences somehow exist previously and then God grants them existence. This would be a contradiction in

27 Avicenna, al-Mubāhathāt, Bīdārfar (ed.), Qum, 1992, §789, 272-273.

28 Avicenna, al-Shifä', al-Ilāhiyyāt, 346-347.

29 Avicenna, al-Shifä', al-Ilāhiyyāt, 347.

Al-Qantara (AQ) XXX 2, julio-diciembre 2009, pp. 403-426 ISSN 0211-3589 
terms. Rather whatever exists has a precarious existence and is not self-sufficient. It is worth noting that another term used for existence employed by Avicenna is anniyya, literally meaning "thatness" in Arabic, referring to the fact of God's existence.

A forerunner of this view was to be found in Alfarabi (d. 950), in his discussion of "thing" in his Book of Letters, a commentary on Aristotle's Metaphysics. "Thing" applies to anything inside or outside the mind, whereas existence only applies to things outside the mind, a position which resembles the Mu'tazilite stance. ${ }^{30}$

Another aspect of Alfarabi's philosophy where the essence and existence distinction makes its appearance is his theory of emanation (later criticised by Averroes, as we shall see): "the concern clearly to mark a hiatus in the emanation scheme which he adopted made al-Fārābī separate 'a principle which has no essence as apart from being (huwiyya)". ${ }^{31}$ In a creationist model as the emanation scheme purports to be the separation between essence and existence becomes pivotal. The essence itself of an individual does not entail its existence. Considered in isolation, the essence of a particular substance is merely possible, and for the actualisation of that substance something else is required. This process ultimately goes back to the being whose existence is identical with its essence, i.e., God. ${ }^{32}$ Obviously this echoes but goes further than the kalām view (more specifically Mu'tazilite) with which Muslim philosophers agreed, that in God all attributes are identical and in particular are not to be viewed as sepa-

30 "Ce mot ['thing'] se dit de tout ce qui a une quiddité (māhiyya), que ce soit extérieur à l'âme ou représenté d'une façon quelconque; dire 'ceci est une chose' équivaut à dire 'ceci a une quiddité'; à l'inverse 'existent' (mawğud) se dit uniquement de ce qui a une quiddité hors de l'âme, et non d'une quiddité seulement représentée: ainsi 'chose' est plus général qu'existant", Jolivet, "Aux origines", 17.

31 Burrell, D., "Essence and Existence: Avicenna and Greek Philosophy", in Institut Dominicain d'Études Orientales du Caire, Mélanges 17, MIDEO, 1986, 53-66, 59. According to Goichon, Avicenna received from al-Fārābī the distinction between essence and existence, and Goichon remarks its absence from the Theology of Aristotle, see Goichon, La distinction de l'essence, 131-133. The terminology for expressing existence is manifold, and Avicenna and al-Fārābī use also huwiyya and anniyya for existence. According to Goichon in explaining huwiyya, "sa forme abstraite [of the personal pronoun, huwa "he"] exprime la manière d'être une substance première... La huwiya est définie au cours d'une explication sur l'aséité divine, car c'est celle-ci qui est établie par la demonstration que Dieu est pleinement soi, huwa, sans aucune influence extrinsèque sur l'origine de son être", Goichon, A.M., Lexique de la Langue Philosophique d'Ibn Sinā (Avicenne), Paris, 1938, 411, n. ${ }^{\circ} 735$.

32 Burrell, "Essence and Existence", 60.

Al-Qantara (AQ) XXX 2, julio-diciembre 2009, pp. 403-426 ISSN 0211-3589 
rate from His essence. Otherwise there would be multiplicity in God, repugnant to the Qur'ānic stress on God's oneness. It goes further in simply stating that God's essence is existence. God is existence par excellence and all being derives from God. The differentiation of essence and existence occurs when the philosophical account of the origin of substances, of the process of generation and corruption, becomes intertwined with the need to establish the world's dependence on God in a philosophical account of creation.

Moreover, as we have seen, the difference between essence and existence in created and finite beings goes hand in hand with Avicenna's metaphysical modalities of the possible and the necessary.

In one sense, all that exists is necessary, and both existence and necessity are primary intelligibles. Necessity means simply, in general terms, certainty or affirmation of existence. In another, more restricted sense, if one introduces causality, only God is necessary in Himself, all other beings are necessary through another, i.e., through their causes. Consequently Avicenna divides all existents into possible in itself and necessary through another (all beings other than God), and necessary in itself (God), also dubbed the necessarily existent. This is consistent with the theory that all existence, i.e., rendering necessary by bringing into existence, is borrowed from God. It is furthermore based on Avicenna's emanation system, which explains the way in which God, through His eternal self-thinking activity, originates or creates the world. By thinking Himself God first gives rise to an intellect, which when thinking God produces a further intellect, and when thinking itself produces the body of the furthest sphere. The second emanated intellect goes on to produce its own sphere and a further intellect. This process is repeated until a total number of ten intelligences is reached. These intellects and respective bodies form the supralunary world, whose interactions are responsible for all that occurs in the world beneath the moon, the world of generation and corruption. It is also important to note that as a result of this cosmology for corruptible beings, possible in themselves and necessary through another, existence is a precarious contingent accident. It is God's constant power that keeps them in existence.

Thus Avicenna can be said to entertain two concepts of existence. One, perhaps more Aristotelian, according to which existence is a primary intelligible and not subsumed under any other category. The second states in no uncertain terms that existence is an accident in 
corruptible beings, and is meant to highlight the world's dependence at any moment on God's granting existence through delegated causality. There is no contradiction between the two views if one thinks of the latter as an important qualification of the first. In one sense, existence is a primary intelligible, not reified, not an accident, and identifiable with whatever exists. In another sense it comes to be attached to a substance's essence through its cause. The latter view is underpinned by Avicenna's cosmology and theory of emanation. Yet one must not overestimate the accidental nature of existence in Avicenna. God only grants existence to substances as an efficient cause through His self-thinking activity. In actually existing beings existence is an accident but the separation in them between essence and existence is conceptual rather than actual.

The distinction between essence and existence had an enormous impact on the history of philosophy. For example, it surfaces in Aquinas, another champion of the view that only God's essence is pure existence, all remaining creatures receiving existence as a gift, as we shall see later. To mention an example already touched on before, the distinction underpins also the fundamental argument for the ontological proof in Descartes' Meditations on First Philosophy. Many other examples could be adduced.

\section{Averroes on existence and his criticism of Avicenna}

Averroes rightly characterises Avicenna's theory in accusing him of considering existence an accident. Averroes was often critical of Avicenna, and this is one of the major attacks he levelled at his predecessor. He states his own views on existence in the Tahäfut al-Tahäfut (The Incoherence of the Incoherence), a direct response to theologian al-Ghazzālī's (d. 1111) scathing criticism of the philosophers in the Tahäfut al-faläsifa (The Incoherence of the Philosophers) and also in his commentaries on Aristotle, particularly the Metaphysics. Averroes was renowned in the Latin Middle Ages as the Aristotle commentator par excellence, and he consciously endeavoured to restore Aristotle's original thought and purge it from distortions accreted to it by his predecessors in the Islamic tradition. In the process he criticises previous Muslim philosophers, especially Avicenna, for deviating from true philosophy, i.e., Greek philosophy and in particular Aristotle's. In this

Al-Qanțara (AQ) XXX 2, julio-diciembre 2009, pp. 403-426 ISSN 0211-3589 
sense, he rejects certain additions or distortions of Aristotle's theories, which, as he endeavours to demonstrate, are not incompatible with Islamic doctrine. On the subject of existence he states:

Existence (anniyya) in the nature of things is a mental (dhihni) concept which affirms the conformity of a thing outside the soul with what is inside the soul. Its meaning is synonymous (murādif) with the true (al-șädiq), and this is what is meant by the existential copula in categorical propositions. The term "existence" is used in two senses; the first convertible with the true, when we ask, for instance, if something exists or not, or whether a certain thing has such and such a quality or not. The second sense relates to the existing things as their genus, in the way the existent is divided into the ten categories, and into substance and accident. When by existent (mawjūd) is understood the true, there is no plurality outside the soul; when by existent is understood what is understood by entity ( $d h \bar{a} t)$ and thing, the term "existent" is attributed to God and to all other things according to priority and posteriority in the way that warmth is attributed to fire and to all warm things. This is the theory of the philosophers. ${ }^{33}$

Averroes understands existence in two ways. The first meaning of existence, the more general, understood as truth, is in effect twofold. On the one hand it means the agreement within the soul between a proposition and a state of affairs. As such it could apply to any entity which has an equivalent outside the mind. On the other hand it consists in verifying whether a certain quality or predicate belongs to a subject. In his theory of existence as truth Averroes brings under the same umbrella 1) actual existence, i.e., the correspondence between the thought and its correspondent outside the mind and 2) the issue whether something possesses a certain quality. However, no reification of existence is to be found here. One might argue that these are two completely different aspects of existence, for instance to say 1) that something is out there and 2) that something has a particular colour. Yet his view goes hand in hand with the position that for him existence is not an accident, since his analysis is logical, rather than metaphysical, and based on what we can truthfully assert of a subject.

The second sense of existence in Averroes goes hand in hand with Aristotle's categories, and echoes Aristotle's principle that being is said in many different ways. It results from this principle insofar as

33 Averroes, Tahäfut al-Tahäfut. The incoherence of the incoherence, translated [modified] from the Arabic with introd. and notes by Simon Van den Bergh, London, 1954, Bouyges, 302, Van den Bergh, 179.

Al-Qanțara (AQ) XXX 2, julio-diciembre 2009, pp. 403-426 ISSN 0211-3589 
existence is an accident only because it is said of substance and consequently of the nine remaining categories. Avicenna had stated that existence is not a genus in relation to the categories, nor does Averroes believe that it is. Nevertheless Averroes follows in the Avicennian vein in distinguishing degrees of predication in regard to existence. Existence in the second sense means that it is attributed primarily to God and secondarily to the remaining existing things. Yet he does not explicitly state that existence is accidental to the substance/essence, a theory he ascribes to Avicenna:

Avicenna believed that existence (anniyya), i.e., the existence of a thing (kawn al-shay'mawjüdan), is something additional to the essence outside the soul and is like an accident of the essence... Avicenna affirms also that what exists as an addition to its essence (dhät) has a cause. Now, existence for Avicenna is an accident which supervenes on the essence (mähiyya). ${ }^{34}$

Clearly although there are parallelisms between Averroes' and Avicenna's theories and they have similar sources, we find important differences. In formulating and recapitulating his position, Averroes, unlike Avicenna, gives prevalence to existence over essence:

The term "existence" is used in two ways, the former signifies the true (sāadiq) and the latter the opposite of non-existence, and in this sense it is that which is divided into the ten categories like their genus. This precedes the things... which are outside the mind and this is what is said of the ten categories according to priority and posteriority. It is in this sense that we say of the substance that it exists by itself and of the accident that it exists through its existing in the existent which subsists by itself. As for the existent which has the meaning of the "true", all the categories participate in it in the same way, and the existent which has the meaning of "true" is something in the minds, namely that a thing is outside the soul in conformity with what is inside the soul. The knowledge of this is prior to the knowledge of its quiddity; that is, knowledge of the quiddity of a thing cannot be asked for, unless it is known that it exists. And as for those quiddities which precede in our minds the knowledge of their existence, they are not really quiddities, but only nominal definitions (sharh ma'nā ism min al-asmá), and only when it is known that their meaning exists outside the soul does it become known that they are quiddities and definitions. And in this sense it is said in the book of the Categories that the intelligible universals of things become existent through their particulars, and that the particulars become intelligible through their universals. And it is said in the De Anima that the faculty by which it is perceived that a thing is a definite particular and exists is another faculty than the faculty by

${ }^{34}$ Averroes, Tahāfut al-Tahāfut, Bouyges, 302-303, Van den Bergh, 179.

Al-Qanțara (AQ) XXX 2, julio-diciembre 2009, pp. 403-426 ISSN 0211-3589 
which the quiddity of the definite particular is perceived, and it is in this way that it is said that particulars exist in the external world ( $f-l-a$ ' $y \bar{a} n)$ and universals in the minds. And there is no difference in the meaning of the "true", whether it concerns material existents or separate existents. ${ }^{35}$

Averroes reiterates here his position on existence, and traces it back to Aristotle. How does his view differ from Avicenna's according to this passage? Existence is said according to the primary substance, an existing individual, then according to the accidents. ${ }^{36}$ Averroes also stresses the primacy of the particular over the universal. The knowledge of the true is based on this knowledge of the particular. He goes as far as to state that we must know something's existence before being able to express ourselves about its essence.

To say that something exists is simply to say that something is the case, or that a thing has a certain property. His interpretation of Aristotle is also noteworthy in that quiddity and existence go hand in hand and cannot be separated.

In commenting on the section devoted to "being" (to on) in Book Delta of Aristotle's Metaphysics, Averroes states that the terms huwiyya and wujüd are equivalent in denoting existence. Although huwiyya is a neologism coined by the translators from the Greek original, it is to be preferred to the more natural wujüd, because this latter indicates the accident. ${ }^{37} \mathrm{He}$ adds that it can be understood as genus or accident, the former as applying to the ten categories and the later as truth. In the Long Commentary on the Metaphysics he further distinguishes, as he does not in the Incoherence of the Incoherence, be-

35 Averroes, Tahāfut al-Tahāfut, Bouyges, 303-304, Van den Bergh, 180. It is important to note the absence, in Arabic, of the verb "to be" to express the link between subject and predicate in present tense affirmative propositions. Thus to express «Zayd is a man» the Arabic employs the personal pronoun huwa, "he", and literally states «Zayd he man» (Zayd huwa rajul). The translators engaged in the translation into Arabic of Aristotle's works had to find Arabic equivalents to the Greek terms and verbs expressing existence, thus coining the neologism "huwiyya" alluded to by Averroes.

${ }^{36}$ G. Roccaro discusses the concept of being/essence (huwiyya) understood chiefly as substance, accident (and the categories), truth, actuality and potentiality in Averroes' Long Commentary on the Metaphysics, in Roccaro, G., "Il concetto di essenza nel Tafsir di Averroè a Metafisica Z 4 di Aristotele", in C. Baffioni (ed.), Averroes and the Aristotelian Tradition, Naples, 2004, 73-81, in particular 74-75.

37 Averroes, Long Commentary on the Metaphysics, in M. Bouyges (ed.), Tafsìr mā ba'd al-tabi'a, Beyrouth, 1938, 553-4.

Al-Qanțara (AQ) XXX 2, julio-diciembre 2009, pp. 403-426 ISSN 0211-3589 
tween the agreement in the mind of subject and predicate and the essence of something existing outside the mind. ${ }^{38}$

What is wrong with assuming that existence is an accident, on Averroes' interpretation?

The theory that existence (wujūd) is something additional to the quiddity and that the existent in its substance is not constituted by it is a most erroneous theory, for this would imply that the term "existence" signified an accident outside the soul common to the ten categories - and this is the theory of Avicenna. And then one may ask about this accident, when it is said to exist, if "exist" is taken here in the meaning of the "true" or whether it is meant that an accident exists in this accident and accidents would be found in it ad infinitum, which is impossible, as we have shown elsewhere. I believe that it is this meaning of "existence" which al-Ghazzāli tried to deny of the First Principle, and indeed in this sense it must be denied of all existents and a fortiori of the First Principle, since it is a false opinion. ${ }^{39}$

Averroes finds a contradiction in the statement that existence is an accident, as appears from the passage above. If existence is an accident of the ten categories, then an infinite regression ensues. If existence is an accident, i.e., a property, then perhaps it can be said to exist, which in itself is an accident like the first. This in turn can have the accident of existence predicated of it, and so there would be no end to the predication of existence as accident. He explains that Avicenna's error results from being misled by the Arabic term. In employing wujūd, which in Arabic is a derived noun (a past participle which literally means "being found"), Avicenna was misled into believing that it stands for an accident rather than the essence of a thing. ${ }^{40}$

Averroes faults this theory for inconsistency but his disagreement with Avicenna is broader than that since it consists in a wholly different conception of beings and causation. In his philosophy, beings have a greater degree of autonomy than for Avicenna, who holds that whatever happens has an external cause. Averroes relies to a much greater degree on an individual's own nature and powers to explain its coming to be and passing away as well as its overall action. This is tied up with his attention to particulars and rejection of the Platonic theory of Forms, common to Avicenna, and Neoplatonism. In this line

38 Ibidem, 561-2.

39 Averroes, Tahāfut al-Tahāfut, Bouyges, 304-305, Van den Bergh, 180-181.

40 Averroes, Long Commentary on the Metaphysics, 557-8.

Al-Qanțara (AQ) XXX 2, julio-diciembre 2009, pp. 403-426 ISSN 0211-3589 
of thought, Averroes rejects the emanation system of Avicenna, and maintains that God, rather than being directly an efficient cause of the universe, acts as a final cause by virtue of being desired by all creatures. Final causality thus becomes the primary driving force in the sublunary as well in as the world above the moon.

He thus rejects the emanation theory that underlies Avicenna's philosophical system because for him it is not the case that God produces the universe as an efficient cause would. There is no emanation of intellects from God to the active intellect. In general as Davidson puts it, in his mature period, Averroes, who endorsed emanation in his youth "contends that, in general, beings do not proceed or emanate from one another". ${ }^{41}$ Primary substances are worthier of existence than in Avicenna's philosophy. Something comes to be by being drawn from potentiality to actuality by an efficient cause that has the characteristic which it enacts in its effect. All of this helps to account for the closer link between essence and existence, and the primacy of existence over essence in the Andalusian philosopher.

To recapitulate, he observes a logical incoherence in treating existence as an accident and favours the actual existing substance over its essence, as this depends on the former. While granting that God exists in a way that other beings do not, he does not appear to focus on the idea of existence as something in itself as does Avicenna.

\section{Excursus on the influence of Avicenna's position}

What is the relevance of Avicenna's and Averroes' views on existence to more recent philosophical debates? While it would be a painstaking task to trace the influence of Avicenna and Averroes on modern philosophy, it is unquestionable that Avicenna sets a trend in the history of philosophy with his distinction between essence and existence and that that view would decisively influence modern discussions, especially by becoming standard in dogmatic theology.

In an early work heavily influenced by Avicennian metaphysics, De ente et essentia, Aquinas adopts the distinction between essence

41 Davidson, H.A., Alfarabi, Avicenna, and Averroes, on Intellect. Their cosmologies, Theories of the Active Intellect, and Theories of Human Intellect, Oxford, 1992, 256.

Al-Qanțara (AQ) XXX 2, julio-diciembre 2009, pp. 403-426 ISSN 0211-3589 
and existence in relation to God and created beings. According to Aquinas, the essence of God, unlike that of other beings, is existence itself, "therefore we find some philosophers who say that God has no quiddity or essence, because His essence is nothing but his existence (esse)", while in other beings existence is something received. ${ }^{42}$ Like Avicenna, Aquinas accepts that the definition of essence does not include existence, and upholds the view that all existence comes from God. However, according to Gilson, in something that actually exists through its cause, existence derives from the essence, which is not the case in Avicenna. ${ }^{43}$

Descartes and Leibniz use this idea for their ontological proof of God's existence, but this view was to be rejected by Kant in his Critique of Pure Reason. Although the terms of Kant's criticism are new and widely distant from Avicenna's context of discussion, the Avicennian roots of the debate are recognisable. Kant contends that existence is not a real predicate or a predicate of a thing. In his refutation of the ontological proof of God's existence in the Critique of Pure Reason, he states that our notion of God may entail omnipotence and omniscience, but not existence. The judgment that something exists is not an analytical judgment, which merely explicates the content of a concept, and existence is not a predicate that could be included in the concept of God or anything else. In other words, to say that God exists is not an analytical judgement. The example used to illustrate this is that there is a contradiction in denying the three angles of a triangle, but there is no contradiction in denying that the triangle actually exists. Hence one cannot prove God's existence simply by appealing to God's perfection. For Kant the assertion that something exists is a synthetic judgment, which "goes beyond" the concept of the subject, and does not merely unfold what is contained in that concept. ${ }^{44}$ This discussion was developed more recently by B. Russell

42 Aquinas, T., De ente et essentia, in Divi Thomae Aquinatis, Opuscula Philosophica, P.Fr. Raymundi M. Spiazzi (ed.), O.P., Romae, 1954, 14-16. But according to Gilson, Aquinas faulted Avicenna for the stress on the distinction: "Saint Thomas d'Aquin lui-même ne l'a-t-il pas critiqué pour avoir, en soutenant cette même thèse, exagéré en quelque sorte la distinction de l'essence et de l'existence et méconnu leur intime corrélation?", Gilson, E., L'être et l'essence, Paris, 1962, 124.

43 Ibidem, 130.

44 Kant, E., Kritik der reinen Vernunft, vol. 3 of Kant's Gesammelte Schriften, herausgegeben von der Königlich Preußischen Akademie der Wissenschaften, Berlin, 1911, 397-403. Kant's predecessor Wolff was heir to the scholastic debates based on

Al-Qanțara (AQ) XXX 2, julio-diciembre 2009, pp. 403-426 ISSN 0211-3589 
and G.E. Moore. The former contends that existence is a predicate at the propositional level like any other. To say that "a man exists" and "x is human" are equivalent. ${ }^{45}$ Moore explains, in a Kantian vein, that the predicate "exists" does not behave like other predicates in a sentence, so it is not a predicate. ${ }^{46}$ However he grants that Russell does not consider existence a property: "according to him [Russell], existence is, after all, in this usage, a "property" or "predicate", though not a property of individuals, but only of prepositional functions". ${ }^{47}$

This qualification is extremely significant. Although Russell considers existence a predicate, he does so in purely logical terms, hence denying a reification of existence. Kant and Moore, who rejects Russell's view, consider existence as something more than a mere logical predicate, so paradoxically their position might be considered to be closer to that of Avicenna, who did not view existence as mere logical predicate, but only as something separate, a metaphysical accident. The paradox lies in the fact that it was the ontological proof, of Avicennian inspiration, that Kant was criticizing in his rejection of existence as an accident. But the afterlife of the Avicenna-Averroes dispute is beyond the scope of this study, its purpose being to show Avicenna's position and how it became the backdrop for later discussions of existence.

Avicenna: "Bien qu'elle soit... une tendance ou un appel vers l'existence, la possibilité intrinsèque, par laquelle se définit l'essence de l'être en général, ne suffit pas à elle seule pour entraîner l'actualisation de celui-ci ou, si l'on veut, pour en faire un être en acte. Pour que cette actualisation s'effectue, quelque chose d'autre est requis", École, J., "Des rapports de l'essence et de l'existence selon Wolff', in Aufklaerung und Skepsis, Studien zur Philosophie und Geistesgeschichte des. 17. und 18. Jahrhunderts, Guenter Gawlick zum 65. Geburtstag, Stuttgart, 1995, 72-79, 76 and "afin d'exprimer le plus fidèlement possible la pensée de Wolff sur les rapports de l'essence et de l'existence, mieux vaudrait dire, comme le faisait Leibniz, que la seconde s'ajoute à la première, pour constituer l'être en acte", 77, "Wolff enseigne que l'existence de l'être nécessaire a sa raison suffisante dans son essence, ce qui revient à dire que son essence est d'exister, et que l'essence de l'être contingent n'entraîne pas son existence qui doit par consequent avoir sa raison suffisante ailleurs qu'en elle, plus précisément dans l'être nécessaire ou Dieu qui la lui confère ou, si l'on veut, l'ajoute à l'idée de son essence, en le créant', 78. I am grateful to Abraham Anderson for referring me to this article and for his suggestions regarding the present study.

45 Russell, B., Introduction to Mathematical Philosophy, London, 1919, 171-172.

46 Moore, G.E., "Is Existence a Predicate?", in T. Baldwin (ed.), Selected Writings, London, 1993, 142-145.

${ }^{47}$ Ibidem, 142.

Al-Qanțara (AQ) XXX 2, julio-diciembre 2009, pp. 403-426 ISSN 0211-3589 


\section{Conclusion}

As we have seen, Avicenna has a twofold theory of existence. On the one, in purely ontological or logical terms, existence is a primary concept that is not apprehended through another concept, but it is a primary given. In that sense, it cannot be said to be an accident. However he holds a more specific view of existence when it comes to his metaphysical system, because then, and perhaps a $\mathrm{Mu}$ 'tazilite influence is discernible here, existence becomes an accident bestowed by God, indirectly through the chain of causes from Himself to the sublunar world, the world of generation and corruption. Avicenna considers existence an accident as a means of stressing the hiatus between God's existence and the existence of any other creature. Therefore the famous distinction between essence and existence, which Avicenna explicitly proclaims, is an integral part of his system, occupying in it a prominent place. There is thus nothing contradictory or nonsensical about this view if it is understood in the proper context of his philosophical system.

Rather than starting with the concept of existence as a separate topic distinct from essence, Averroes, following Aristotle, does not think of existence as separate from existing beings. Rather than speaking of "existence" in the abstract, one speaks of existing beings or substances. There is a primacy of substance as in Aristotle. Yet the germs of both theories, 1) the distinction between essence and existence which results in the view of existence as an accident and 2) the view of existence as a primary intelligible identical with existing beings, and the primacy of existence over essence, can be traced back to Aristotle. There are other points in common between Avicenna and Averroes, even if the latter does not acknowledge the similarity. In neither theory is existence an accident when one is speaking of God, and in terms of causality they both admit that God grants existence or creates, in Avicenna as the source of emanation, in Averroes as object of desire, final cause, and so as unmoved mover. It is important to highlight however a significant difference in the understanding of efficient causality which is connected with their views on existence. For Avicenna, the efficient cause or agent bestows existence on the effect. For Averroes, in turn, the agent merely draws the effect from potentiality into actuality. ${ }^{48}$

48 Averroes, Tahāfut al-Tahāfut, Bouyges, 153, Van den Bergh, 91.

Al-Qanțara (AQ) XXX 2, julio-diciembre 2009, pp. 403-426 ISSN 0211-3589 
To recapitulate, what are the main differences between Avicenna and Averroes concerning existence and essence? As a metaphysician, Avicenna thinks of essence and existence as separate, and his theory may lead to a reification of existence which is completely lacking in Averroes. The latter, in turn, identifies, in an Aristotelian way, existence with existing beings, and does not think of existence as a separate entity (which as he points out would lead to inconsistency). He identifies existence with truth, which is a logical category, and with the correct, truthful pairing of subjects and their predicates. Thus existence does not constitute a thing in itself. He does not think of it as predicate or attribute. To say that something exists presupposes empirical verification but adds nothing to the thing itself which is said to exist. But the roots of the difference between the two philosophers on this issue lie deeper, and it must be understood against the background of their philosophical systems, and broader views on the causal structure of the universe. Their theories on existence and essence are grounded in their metaphysics. Avicenna considers existence in its own right. Averroes, in contrast, locates existence in particular existing beings, and shows an empirical vein which is also apparent in his treatment of other issues.

Recibido: 07/09/2007

Aceptado: 05/06/2008 